\title{
Tracer measurements in the tropical tropopause layer during the AMMA/SCOUT-O3 aircraft campaign
}

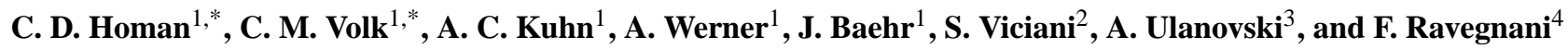 \\ ${ }^{1}$ Institute for Atmospheric and Environmental Sciences, Goethe University Frankfurt, Germany \\ ${ }^{2}$ Istituto Nazionale di Ottica Applicata, Florence, Italy \\ ${ }^{3}$ Central Aerological Observatory, Dolgoprudny, Russia \\ ${ }^{4}$ CNR Institute of Atmospheric Science and Climate, Bologna, Italy \\ *now at: Department of Physics, University of Wuppertal, Germany
}

Received: 29 September 2009 - Published in Atmos. Chem. Phys. Discuss.: 25 November 2009

Revised: 2 April 2010 - Accepted: 8 April 2010 - Published: 19 April 2010

\begin{abstract}
We present airborne in situ measurements made during the AMMA (African Monsoon Multidisciplinary Analysis)/SCOUT-O3 campaign between 31 July and $17 \mathrm{Au}-$ gust 2006 on board the M55 Geophysica aircraft, based in Ouagadougou, Burkina Faso. $\mathrm{CO}_{2}$ and $\mathrm{N}_{2} \mathrm{O}$ were measured with the High Altitude Gas Analyzer (HAGAR), CO was measured with the Cryogenically Operated Laser Diode (COLD) instrument, and $\mathrm{O}_{3}$ with the Fast Ozone ANalyzer (FOZAN).

We analyse the data obtained during five local flights to study the dominant transport processes controlling the tropical tropopause layer (TTL, here $\sim 350-375 \mathrm{~K}$ ) and lower stratosphere above West-Africa: deep convection up to the level of main convective outflow, overshooting of deep convection, and horizontal inmixing across the subtropical tropopause. Besides, we examine the morphology of the stratospheric subtropical barrier.

Except for the flight of 13 August, distinct minima in $\mathrm{CO}_{2}$ mixing ratios indicate convective outflow of boundary layer air in the TTL. The $\mathrm{CO}_{2}$ profiles show that the level of main convective outflow was mostly located at potential temperatures between 350 and $360 \mathrm{~K}$, and for 11 August reached up to $370 \mathrm{~K}$.

While the $\mathrm{CO}_{2}$ minima indicate quite significant convective influence, the $\mathrm{O}_{3}$ profiles suggest that the observed convective signatures were mostly not fresh, but of older origin (several days or more). When compared with the mean $\mathrm{O}_{3}$
\end{abstract}

profile measured during a previous campaign over Darwin in November 2005, the $\mathrm{O}_{3}$ minimum at the main convective outflow level was less pronounced over Ouagadougou. Furthermore $\mathrm{O}_{3}$ mixing ratios were much higher throughout the whole TTL and, unlike over Darwin, rarely showed low values observed in the regional boundary layer.

Signatures of irreversible mixing following overshooting of convective air were scarce in the tracer data. Some small signatures indicative of this process were found in $\mathrm{CO}_{2}$ profiles between 390 and $410 \mathrm{~K}$ during the flights of 4 and $8 \mathrm{Au}-$ gust, and in CO data at $410 \mathrm{~K}$ on 7 August. However, the absence of expected corresponding signatures in other tracer data makes this evidence inconclusive, and overall there is little indication from the observations that overshooting convection has a profound impact on gas-phase tracer TTL composition during AMMA.

We find the amount of photochemically aged air isentropically mixed into the TTL across the subtropical tropopause to be not significant. Using the $\mathrm{N}_{2} \mathrm{O}$ observations we estimate the fraction of aged extratropical stratospheric air in the TTL to be $0.0 \pm 0.1$ up to $370 \mathrm{~K}$ during the local flights. Above the TTL this fraction increases to $0.3 \pm 0.1$ at $390 \mathrm{~K}$.

The subtropical barrier, as indicated by the slope of the correlation between $\mathrm{N}_{2} \mathrm{O}$ and $\mathrm{O}_{3}$ between 415 and $490 \mathrm{~K}$, does not appear as a sharp border between the tropics and extratropics, but rather as a gradual transition region between $10^{\circ} \mathrm{N}$ and $25^{\circ} \mathrm{N}$ where isentropic mixing between these two regions may occur.

\section{Correspondence to: C. D. Homan}

(c.homan@iau.uni-frankfurt.de) 


\section{Introduction}

The tropical tropopause layer (TTL), the region in the tropics where air has characteristics of both the stratosphere and the troposphere, is a critical region of the atmosphere. It is the main region for air entering the stratosphere and therefore it sets the chemical boundary conditions for the stratosphere. The TTL is commonly defined as the layer extending from the level of main convective outflow at $10-14 \mathrm{~km}$ to the cold point tropopause at about $16-19 \mathrm{~km}$ altitude (Gettelman and Forster, 2002). Laterally, the TTL is bounded by the position of the subtropical jets. Processes active in the TTL include the global-scale circulations in the stratosphere (Brewer-Dobson) and troposphere (Hadley-Walker), largescale and small-scale atmospheric waves, convection organised on all time and space scales, mixing, radiative heating and cooling, chemistry and cloud microphysics.

Satellite observations and 2-D or 3-D transport models provide a general picture of the TTL, but typically cannot well resolve spatial, in particular vertical, variations within the layer. Hence, highly resolved in situ measurements of trace gases and their use as tracers of atmospheric transport have proven extremely useful for studying the radiative, chemical, and dynamical properties of the TTL (e.g., Park et al., 2007a). Tracers are compounds whose lifetimes are longer than the timescales of the processes transporting them, such that their distributions are mainly determined by dynamical processes. In the stratosphere, the correlation between two long-lived tracers (tracer-to-tracer correlation) often turns out to be very compact (Plumb and Ko, 1992). The form and curvature of the correlation curve is dependent on the lifetimes of the tracers and on transport processes. Different atmospheric regions may exhibit different correlation curves between tracers. Variations from these correlations may be caused by horizontal or vertical mixing between the regions or by chemistry. Hence, tracer-to-tracer correlations are a particularly useful tool to study transport and mixing between the troposphere and the stratosphere (e.g., Hoor et al., 2002), or between the tropical and extratropical stratosphere (e.g., Volk et al., 1996).

Over the last decade various field campaigns have taken place to obtain in situ observations of the TTL and get more insight into the different processes taking place in this layer of the atmosphere. Several European campaigns were conducted with the Russian M55-Geophysica high-altitude aircraft. The APE-THESEO campaign took place in February and March 1999 over the western equatorial Indian Ocean (Stefanutti et al., 2004; MacKenzie et al., 2006). Cairo et al. (2008) show with observations made above a tropical cyclone during this campaign that cyclones may induce horizontal stirring of the lower stratosphere, possibly promoting irreversible entrainment of midlatitude stratospheric air into the tropical zone. The TROCCINOX campaign took place in February 2005 from Aracatuba, Brasil. Konopka et al. (2007) show with a comparison of the in situ measurements of ozone, water vapour, $\mathrm{NO}, \mathrm{NOy}, \mathrm{CH}_{4}$ and $\mathrm{CO}$ with $\mathrm{CLaMS}$ model simulations that vertical mixing, mainly driven by the vertical shear in the tropical flanks of the subtropical jets and, to some extent, in the outflow regions of large-scale convection, offers an explanation for the upward transport of trace species from the main convective outflow at around $350 \mathrm{~K}$ up to the tropical tropopause around $380 \mathrm{~K}$. The SCOUTO3 campaign over Darwin, Australia in November 2005 was focused on studying the effect of deep convection on the composition of the TTL (Vaughan et al., 2008). Schiller et al. (2009) found highly localised layers of enhanced water vapour up to $420 \mathrm{~K}$ which could be traced to direct injection by overshooting turrets during this campaign.

In situ measurements of tracers in the TTL have also been conducted using the NASA ER-2 and WB-57F aircraft. Marcy et al. (2007) have presented measurements of $\mathrm{HCl}$, $\mathrm{O}_{3}, \mathrm{HNO}_{3}, \mathrm{H}_{2} \mathrm{O}, \mathrm{CO}, \mathrm{CO}_{2}$ and $\mathrm{CH}_{3} \mathrm{Cl}$ in the tropical upper troposphere and lower stratosphere (UT/LS) during the Pre-AVE campaign over Costa Rica in January 2004. They infer that a significant amount of stratospheric air and $\mathrm{O}_{3}$ were present in the TTL, making it distinct from both the stratosphere and the remainder of the troposphere. Park et al. (2007a) have presented $\mathrm{CO}_{2}$ measurements during the PreAVE, CR-AVE and TWP-ICE campaign in Costa Rica and Australia. They suggest that the TTL is composed of two layers, the lower TTL which is subject to significant inputs of convective outflow, and the upper TTL, where air ascends slowly and ages uniformly. They calculate a mean age of air entering the lower stratosphere of 26 days during $\mathrm{NH}$ winter. Tuck et al. (2003) have analyzed tracers and thermodynamical data from various ER-2 and WB57F aircraft campaigns and documented significant transport from the lower midlatitudes stratosphere toward the tropics, coming to the conclusion that the characteristics of the TTL are determined by a combination of subtropical jet stream dynamics and inner tropical ascent via deep convection.

Until now, in situ measurements of tracers throughout the TTL have not been reported during NH summer and none have been made above the African continent. However, this region may play an important role in troposphere-tostratosphere transport. Ricaud et al. (2007) present satellite data of $\mathrm{N}_{2} \mathrm{O}, \mathrm{CH}_{4}$ and $\mathrm{CO}$ and radar data in the tropical tropopause region during $\mathrm{NH}$ spring and suggest that rapid uplift over land convective regions, in particular over Africa, may be the dominant process of troposphere-to-stratosphere exchange. However, this view is in contrast to a number of other studies showing that the African region is not an important contributor to troposphere-to-stratosphere transport compared in particular to Southeast Asia and the Western Pacific (Fueglistaler et al., 2004; Berthet et al., 2007; Barret et al., 2008; Park et al., 2007b).

Beginning in 2001, the large project AMMA (African Monsoon Multidisciplinary Analyses) was set up to study the West-African monsoon and its influence on the physical, chemical and biological environment, regionally and 
globally. The overall objective of the project was to provide the underpinning science that relates variability of the West African Monsoon to issues of health, water resources, food security and demography for West-African nations and to define and implement relevant monitoring and prediction strategies (www.amma-international.org). Within the frame of AMMA and the project SCOUT-O3 (Stratospheric-Climate Links with Emphasis on the Upper Troposphere and Lower Stratosphere) an aircraft campaign took place at the peak of the summer monsoon period in 2006, probing the air from the boundary layer up to the stratosphere (Cairo et al., 2010). The campaign took place in July/August 2006 and was based in Ouagadougou, Burkina Faso. The main aim of this aircraft campaign was to quantify the contribution of different air mass origins on the chemical composition of the TTL during the summer monsoon over West Africa. At this time of year the TTL can be impacted by recent local or regional convective uplift, but also by uplift from the lower troposphere upwind (e.g. over Asia), intrusion of air from the midlatitude lower stratosphere or cross-hemispheric transport of air masses from the Southern Hemisphere (Law et al., 2010). A detailed description of the meteorological situation during the West-African monsoon in 2006 can be found in Janicot et al. (2008).

In this paper we will present in situ tracer data of $\mathrm{CO}_{2}$, $\mathrm{N}_{2} \mathrm{O}, \mathrm{O}_{3}$ and $\mathrm{CO}$ that were obtained on board the M55 Geophysica aircraft during the AMMA/SCOUT-O3 project and analyse them regarding the principal transport processes that control the chemical composition of the TTL and tropical lower stratosphere above West-Africa. Vertical profiles and correlations between the various species, serving as stratospheric tracers, as boundary layer tracers, or ageof-air tracers will be used to contrast observations of the background TTL with convectively influenced air, to diagnose irreversible mixing of convectively overshooting air with the background TTL, to assess isentropic mixing across the subtropical tropopause and to study the morphology of the stratospheric subtropical transport barrier.

\section{In situ measurements}

Tracer measurements were made between 31 July and $17 \mathrm{Au}$ gust 2005 on board the M55 Geophysica aircraft from (and during transfer to/from) Ouagadougou, Burkina Faso $\left(12^{\circ} \mathrm{N}\right.$, $\left.1^{\circ} \mathrm{W}\right)$. A total of nine flights were performed with measurements from the free troposphere up to the tropical lower stratosphere around 20 kilometer altitude. Four transfer flights were made between Verona (Italy), Marrakech (Morocco) and Ouagadougou (Burkina Faso). Five local flights between $4^{\circ} \mathrm{N}$ and $17^{\circ} \mathrm{N}$ latitude and $3^{\circ} \mathrm{W}$ and $3^{\circ} \mathrm{E}$ longitude were made to study mesoscale convective systems (MCS) and long range transport, and to validate the CALIPSO satellite. A brief overview of the flights is given in Table 1. A
Table 1. Overview of flights during AMMA-SCOUT-O3.

\begin{tabular}{lcl}
\hline Date of flight & Time (UTC) & Goal \\
\hline 31 Jul 2006 & $05: 50-09: 13$ & Transfer flight-UTLS profile \\
1 Aug 2006 & $10: 59-14: 59$ & Transfer flight-UTLS profile \\
4 Aug 2006 & $08: 26-12: 13$ & Long range transport \\
7 Aug 2006 & $12: 15-16: 07$ & MCS close up \\
8 Aug 2006 & $11: 46-15: 31$ & CALIPSO validation \\
11 Aug 2006 & $14: 44-18: 22$ & MCS aged outflow \\
13 Aug 2006 & $12: 50-16: 23$ & Long range transport \\
16 Aug 2006 & $13: 27-15: 16$ & Transfer flight-UTLS profile \\
17 Aug 2006 & $04: 10-07: 51$ & Transfer flight-UTLS profile \\
\hline
\end{tabular}

more extended overview of the flights and the Geophysica campaign can be found in Cairo et al. (2010).

A suite of long-lived tracers $\left(\mathrm{CO}_{2}, \mathrm{~N}_{2} \mathrm{O}, \mathrm{CFC}-12\right.$, $\mathrm{CFC}-11, \mathrm{H}-1211, \mathrm{SF}_{6}, \mathrm{CH}_{4}, \mathrm{H}_{2}$ ) was measured by the University of Frankfurt's High Altitude Gas Analyzer (HAGAR) on all flights except on 7 August when a software failure occurred. HAGAR is a two-channel in situ gas chromatograph (GC) that is combined with a $\mathrm{CO}_{2}$ sensor (LI-COR 6251). The two GC-channels with electron capture detectors (ECD) measure the long-lived tracers $\mathrm{N}_{2} \mathrm{O}, \mathrm{CFC}-12$, CFC-11, $\mathrm{H}-1211, \mathrm{CH}_{4}, \mathrm{SF}_{6}$ and $\mathrm{H}_{2}$ with a time resolution of $90 \mathrm{~s}$. The $\mathrm{CO}_{2}$ sensor achieves a time resolution of $5 \mathrm{~s}$ using non-dispersive infrared absorption (NDIR). A detailed description of the instrument can be found in Riediger (2000) and Strunk (1999).

Frequent in flight calibrations within the instrument were performed in order to meet the specifications for accuracy and precision. All measurements are directly traceable to the current WMO scales based on intercalibrations against standards of NOAA/GMD or (for $\mathrm{CO}_{2}$ ) the University of Heidelberg (I. Levin). For $\mathrm{CO}_{2}$ the mean precision during all flights was $0.3 \mathrm{ppm}$. The precisions for the measurement of the other tracers are in the order of $0.5-3 \%$; for the $\mathrm{N}_{2} \mathrm{O}$ measurements used in this study it is better than $1.5 \%$. Accuracies of the HAGAR measurements are limited by the precision and are thus only slightly larger than these precision values.

Additionally, $\mathrm{CO}$ was measured with a precision of $1 \%$ and accuracy of $6-9 \%$ by the Italian institute INOA (Istituto Nazionale di Ottica Applica) with the tunable diode laser COLD (Cryogenically Operated Laser Diode) as described in detail by Viciani et al. (2008). Ozone was measured with the Fast Ozone ANalyzer (FOZAN) of the Central Aerological Observatory (CAO, Russia) with an accuracy of 10\% (Ulanovsky, 2001). Mixing ratios for all gas measurements are expressed in dry mole fractions. Flight parameters as altitude, pressure and temperature were recorded by the aircraft. 


\section{Analysis of main transport processes}

The results of the analysis of the different transport processes occurring in the summer TTL over West-Africa will be discussed in the following sections. Section 3.1 describes both main convective outflow as well as overshooting convection, Sect. 3.2 describes isentropic stratospheric inmixing across the subtropical tropopause and Sect. 3.3 describes isentropic mixing across the subtropical barrier in the lower stratosphere. Each section will have a short introduction about the concepts of the transport process described.

\subsection{Convection}

Convection plays an important role in determining the thermodynamic and chemical properties of the TTL. It can provide a fast pathway for halogenated very short lived species and other boundary layer trace gases to reach the TTL and subsequently the stratosphere, where they could contribute to the depletion of ozone. The amount of very short lived species that can reach the stratosphere thus depends crucially on the convective mass flux into the TTL as well as the maximum altitude level that is reached by deep convection. The impact of convection on the TTL may also significantly depend on the fraction and composition of mid-tropospheric air entrained into convection (Fridlind et al., 2004).

There are two mechanisms in which convection contributes to vertical transport through the TTL. The first is direct convective uplift to the level of neutral buoyancy, which is located at a potential temperature of at most $365 \mathrm{~K}$ (Folkins et al., 2000). At this level the potential temperature becomes equal to the highest equivalent potential temperatures realized in the marine boundary layer. It is therefore near the maximum altitude an air parcel from the boundary layer can reach by undiluted, non-overshooting ascent (Reid and Gage, 1981). This convection up to the level of neutral buoyancy can be followed by slow diabatic ascent up to and across the tropopause due to radiative heating and the dynamical forcing by the Brewer Dobson circulation (Folkins et al., 1999). The typical time scales for this diabatic transport, as derived from numerical models and tracer measurements, range between 2 and 3 months for the upward transport from a potential temperature of $350 \mathrm{~K}$ up to 390 and $420 \mathrm{~K}$, respectively (e.g., Andrews et al., 1999).

The second mechanism, by which convection can influence the TTL to much higher levels than its neutral buoyancy level, is irreversible mixing of air following dynamic overshooting (Danielsen, 1982, 1993; Sherwood, 2000). When an air parcel overshoots its level of neutral buoyancy it will be colder than the surrounding air and start descending back to its equilibrium level. However, when it entrains and mixes with warmer surrounding air it will come to rest at a warmer, higher equilibrium level, i.e. its potential temperature increases (Danielsen, 1982). This overshooting of convection occurs predominantly above continental areas (Liu and Zipser, 2005; Zipser et al., 2006) and in large mesoscale convective systems (Rossow and Pearl, 2007), which are generated regularly over West-Africa in the monsoon period, thereby providing a fast pathway for boundary layer air into the upper TTL or even the lower stratosphere. During AMMA, in fact, moist layers were observed above the tropopause over Niger up to $19 \mathrm{~km}$ and have been attributed to geyser-like injection of ice particles over overshooting turrets (Khaykin et al., 2009). Although impact of overshooting convection on the upper TTL and lower stratosphere is generally accepted and can be numerically simulated (e.g., Arteta et al., 2009; Liu et al., 2010), its importance at global scale is less clear.

In this section the two mechanisms for convective influence will be studied with help of the tracer data measured during AMMA/SCOUT-O3. In Sect. 3.1.1 we will examine the first mechanism and assess the level of main convective outflow and the influence of local and aged convection on the $\mathrm{CO}_{2}$ profiles. In Sect. 3.1.2 we will examine the data for signatures of overshooting air.

\subsubsection{Main convective outflow}

$\mathrm{CO}_{2}$ can be used as a tracer for continental convection because its mixing ratio is reduced in the boundary layer due to uptake by vegetation during daytime. Deep convection during the African monsoon season peaks in the evening (Sultan et al., 2007) when boundary layer $\mathrm{CO}_{2}$ is expected to be around its minimum. Convective transport of boundary layer air into the TTL during the monsoon season therefore results in a layer of low $\mathrm{CO}_{2}$ mixing ratios around the level of main convective outflow. Above this level, diabatic ascent is expected to dominate convection, vertical mixing and mixing of older air from mid-latitudes into the tropics. Hence, a coherent "tape recorder" signal due to the monotonic aging of the slowly ascending air and the progressing $\mathrm{CO}_{2}$ seasonal cycle in the tropospheric boundary layer can be observed (Boering et al., 1996; Park et al., 2007a).

In this section we will discuss the strength and height of the main convective influence with help of the $\mathrm{CO}_{2}$ profiles and compare with results of an analysis by Law et al. (2010). Law et al. (2010) calculate the fraction of measured air sampled between 350 and $365 \mathrm{~K}$ that has potentially been influenced by recent convection with help of ECMWF backtrajectories and infrared satellite images identifying convective clouds. They label an airmass as possibly recently convectively influenced when its backward trajectory crossed a region whose cloud top radiance was below $200 \mathrm{~K}$ within a longitudinal band from $30^{\circ} \mathrm{W}$ to $40^{\circ} \mathrm{E}$, corresponding to an age of at most three to four days.

Figure 1 shows the vertical $\mathrm{CO}_{2}$ profiles for the four local flights on 4, 8, 11 and 13 August, respectively. Mixing ratios as low as $372 \mathrm{ppm}$ are observed in the daytime boundary layer over Ouagadougou; even lower values could be present in rural areas. The influence of vegetative uptake 


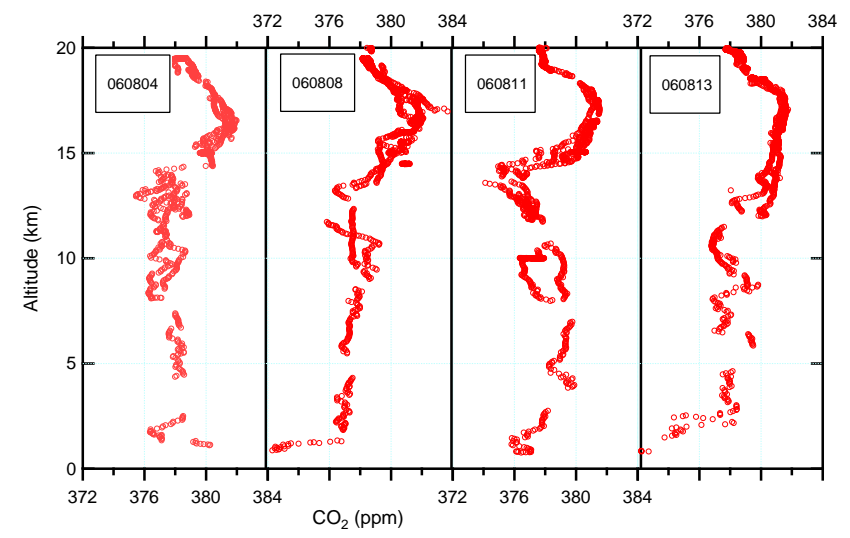

Fig. 1. Vertical profiles of $\mathrm{CO}_{2}$ for the local flights on $4,8,11$ and 13 August, respectively.

of $\mathrm{CO}_{2}$ is getting smaller in the free troposphere, resulting in higher mixing ratios of around $380 \mathrm{ppm}$. Convection during afternoon and evening transports the $\mathrm{CO}_{2}$-depleted boundary layer air up to about $13-14 \mathrm{~km}$, or a potential temperature level of $350 \mathrm{~K}$ (Fig. 2), where again a distinct layer with low mixing ratios is observed. Above this level the typical coherent "tape recorder" signal is observed.

The flight of 11 August shows the highest and strongest outflow signature, with mixing ratios as low as $374 \mathrm{ppm}$ found up to $370 \mathrm{~K}$. This flight aimed specifically at sampling air influenced by a large and intense MCS that had crossed westward across Burkina Faso during the previous days (Cairo et al., 2010). Law et al. (2010) also find that of all flights performed during the campaign, the TTL sampled during the flight on 11 August was most influenced by recent convection. They calculate that for this flight $\sim 55 \%$ of the measured air between 350 and $365 \mathrm{~K}$ was possibly influenced by recent convective activity. Our $\mathrm{CO}_{2}$ observations suggest that convective outflow of this intense MCS in fact reached unusually high potential temperatures of $370 \mathrm{~K}$.

For the flight of 8 August, Law et al. (2010) also indicate possible convective influence for $\sim 40 \%$ of the air sampled between 350 and $365 \mathrm{~K}$. This agrees well with the $\mathrm{CO}_{2}$ profile, which shows a level of main convective outflow at $350 \mathrm{~K}$, albeit with a $\mathrm{CO}_{2}$ minimum that is less pronounced than on 11 August. However, above this level the "tape recorder" signal is less compact than during the other flights, which might be an indication of overshooting convection, which will be discussed in the next section.

For the flight of 4 August, the $\mathrm{CO}_{2}$ profile shows again a recognisable level of main convective outflow at $355 \mathrm{~K}$, again less distinct as for the flight of 11 August. Law et al. (2010) infer here a possible influence of recent convection for only $\sim 10 \%$ of the air between 350 and $365 \mathrm{~K}$ during that day.

Least influence of convection is evident in the profile of 13 August, where an outflow level can hardly be discerned, with mixing ratios at $13 \mathrm{~km}$ as high as in the free troposphere.

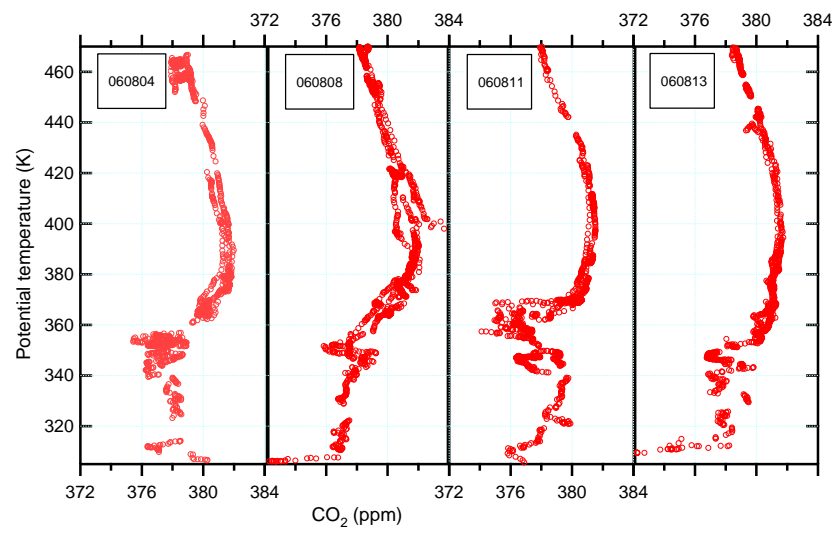

Fig. 2. Potential temperature profiles of $\mathrm{CO}_{2}$ for the flights on 4,8 , 11 and 13 August, respectively.

This again agrees well with the analysis of Law et al. (2010), who also find least possible influence of recent convection $(\sim 5 \%)$ during this flight, and in fact not even convective uplift of the trajectories within the previous 10 days.

Overall, the observed features in the $\mathrm{CO}_{2}$ profiles and their relative strengths are thus qualitatively in line with the fractions of sampled air having recently (within about 4 days) passed over convective systems, as calculated by Law et al. (2010). An exception is the flight of 4 August where the observed pronounced $\mathrm{CO}_{2}$ reductions by $2-3 \mathrm{ppm}$ in the convective outflow region cannot easily be explained by the small recent convective input of $10 \%$, unless regional boundary layer mixing ratios are much lower on the average than those actually observed over Ouagadougou. Another, more likely, explanation is that the $\mathrm{CO}_{2}$ minima are not only due to recent convection, but to a larger part caused by older convection having occurred more than four days earlier. Since $\mathrm{CO}_{2}$ is chemically conserved in the TTL, it is not possible to distinguish between the effects of recent and older convection with help of the $\mathrm{CO}_{2}$ profiles. However $\mathrm{O}_{3}$ profiles can give an indication whether the convection was of recent or of older origin.

In the tropical boundary layer typical ozone mixing ratios range from 15 to $40 \mathrm{ppb}$ (Folkins and Martin, 2005). Deep convection will transport this $\mathrm{O}_{3}$ poor air together with ozone precursors from the tropical boundary layer into the TTL, where, as long as no new convective input takes place, the mixing ratio will steadily increase by photochemical production until it reaches its steady state. Therefore, $\mathrm{O}_{3}$ mixing ratios are an indication for the convective replacement timescale over a region. However, not only convection, photochemical production, and the time since the air has last experienced convective flushing determine the $\mathrm{O}_{3}$ mixing ratios in the TTL. The $\mathrm{O}_{3}$ budget in the TTL can also be significantly affected by isentropic stratospheric inmixing bringing in extratropical stratospheric air with high $\mathrm{O}_{3}$ mixing ratios. Vertical mixing, e.g. following overshooting of air, may also 


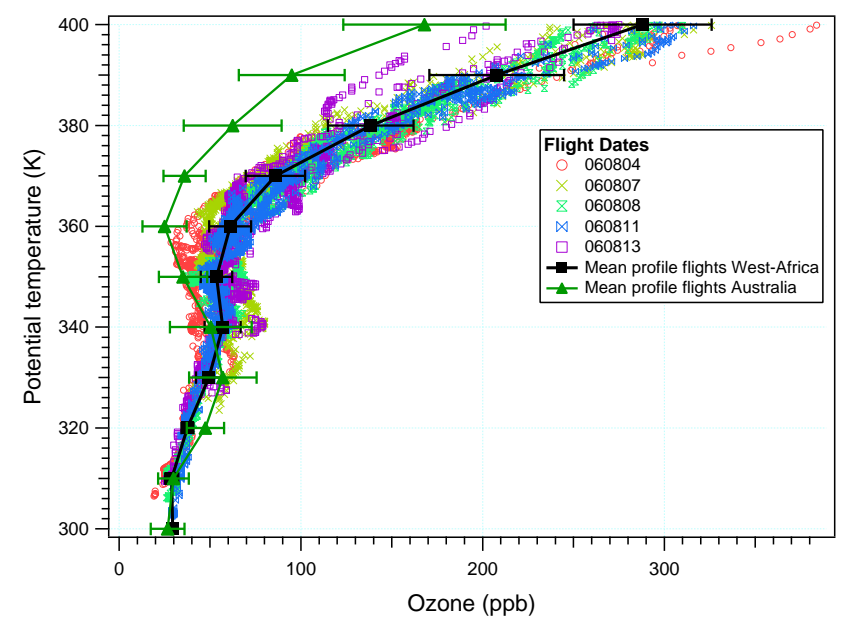

Fig. 3. Ozone profiles for the five local flights. The average profiles is indicated with the black line. The green line represents the average ozone profile for the SCOUT-O3 campaign over Australia in November/December 2005.

mix down higher ozone concentrations from higher altitudes. We show in Sect. 3.2 that horizontal stratospheric inmixing, however, is not significant during the four flights considered here. Mixing following overshooting will be discussed in the next section (Sect. 3.1.2).

Figure 3 shows the ozone profiles during the AMMA campaign. The average profile of all five local flights is indicated as the black line. For comparison, the dark green line represents the average ozone profiles during the SCOUT-O3 campaign, which took place in November and December 2005 above northern Australia. This latter profile shows the typical $\mathrm{S}$-shape, with low $\mathrm{O}_{3}$ mixing ratios of $30 \mathrm{ppb}$ over the marine boundary layer, increasing concentrations in the free troposphere, again low $\mathrm{O}_{3}$ mixing ratios at the level of main convective outflow, and above that increasing mixing ratios due to the photochemical production of $\mathrm{O}_{3}$ in the lower stratosphere.

The AMMA-SCOUT-O3 profiles also show this S-shape profile, although less pronounced. Again, concentrations are on average about $30 \mathrm{ppb}$ in the boundary layer; this mean value above Ouagadougou agrees also well with that observed in the boundary layer over Niamey, Niger, by regularly launched ozone sondes (Cairo et al., 2010) and is thus thought to be fairly representative for a wider region. In the free troposphere $\mathrm{O}_{3}$ increases with height up to around $60 \mathrm{ppb}$ at a potential temperature level of $340 \mathrm{~K} . \mathrm{O}_{3}$ mixing ratios at the level of main convective outflow, however, are much higher on average than those observed during the SCOUT-O3 campaign or in the boundary layer during AMMA-SCOUT-O3. For most of the flights no boundary layer values are observed at the main level of convective outflow $(\sim 355 \mathrm{~K})$, thereby suggesting that there is no major flushing of the TTL by recent convection of $\mathrm{O}_{3}$-poor bound- ary layer air. The absence of this flushing results in increased $\mathrm{O}_{3}$ mixing ratios due to production by NOx from lightning (LiNOx) (e.g., Thompson et al., 2000; Sauvage et al., 2007; Barret et al., 2010) and other ozone precursors. Law et al. (2010) indicate that a large part of the air in the TTL originated from Asia about a week earlier, where uplift of these ozone precursors could have taken place. An exception appears to be the flight on 4 August when values as low as $30 \mathrm{ppb}$ observed at a level of $355 \mathrm{~K}$ indicate more recent convective flushing.

Above $370 \mathrm{~K}$ the $\mathrm{O}_{3}$ mixing ratios are up to twice as high as during the SCOUT-O3 campaign. Randel et al. (2007) show that in a narrow vertical layer between $\sim 16$ and $19 \mathrm{~km}$ $(\sim 375-450 \mathrm{~K})$ approximately a factor 2 change in ozone between the minimum (during $\mathrm{NH}$ winter) and maximum (during $\mathrm{NH}$ summer) takes place due to variations in vertical transport associated with mean upwelling in the lower stratosphere (the Brewer Dobson circulation). Thus, the higher mixing ratios observed during AMMA in the lower stratosphere are probably caused by the seasonal difference in upwelling due to the Brewer Dobson circulation.

In summary, the $\mathrm{CO}_{2}$ profiles show that the region around West-Africa is highly influenced by convection up to $355 \mathrm{~K}$, during 11 August even up to $370 \mathrm{~K}$. Clearly pronounced levels of main convective outflow are observed during three of the four flights. However, $\mathrm{O}_{3}$ profiles strongly suggest that this convectively influenced air is mostly of older origin, and has been transported for at least several days before being measured. Only the observations of 4 August exhibit some signatures of recent convection in the $\mathrm{O}_{3}$ profile. Overall, these results are in good agreement with the findings of Law et al. (2010).

\subsubsection{Overshooting of convection}

Now we examine potential signatures of overshooting convection in the tracer data by observations of $\mathrm{CO}, \mathrm{CO}_{2}$ and $\mathrm{O}_{3}$.

In Fig. 4 the $\mathrm{CO}_{2}$ profiles during AMMA/SCOUT-O3 are plotted in one figure, with their average represented by the black line. On 8 August there are large deviations from this average between 390 and $420 \mathrm{~K}$. Both enhanced and reduced values of $\mathrm{CO}_{2}$ can be found at this level. On 4 August there are also some reduced values between 400 and $420 \mathrm{~K}$.

The enhanced values on 8 August cannot be explained by transport processes; given they occur shortly after a calibration phase of the instrument we cannot completely rule out an unusual instrumental instability. The low values could be an indication of irreversible mixing of overshooting air. If irreversible mixing takes place during or following convective overshoot, air parcels originating from the boundary layer with a potential temperature of 350-360 K (the level of neutral buoyancy) will mix with air masses with a higher potential temperature along a mixing line. In practice, mixing may proceed along a multitude of such mixing lines resulting 


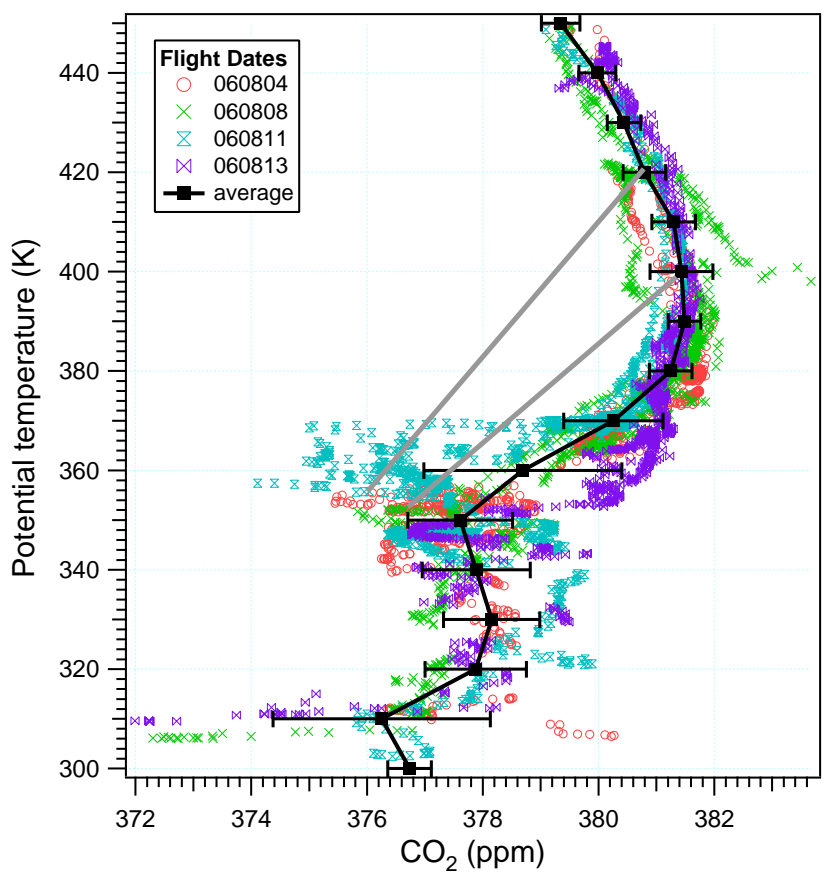

Fig. 4. $\mathrm{CO}_{2}$ profiles for the local flights during AMMA/SCOUTO3. Average profile in black. Two examples of possible mixing lines are presented by the grey lines.

in a mixing band in a profile plot (provided sufficient sampling). In Fig. 4, two possible idealized mixing lines are displayed. They indicate that, in order to explain the signatures, mixing would have occurred between air parcels with potential temperatures of approximately $355 \mathrm{~K}$ and $400-420 \mathrm{~K}$, that is overshooting convection would have reached up to $17-$ $18 \mathrm{~km}$.

Overshooting convection can also be diagnosed in tracertracer correlations. Without mixing, the correlation between a tropospheric (e.g. $\mathrm{CO}, \mathrm{CO}_{2}$ ) and a stratospheric tracer (e.g. $\mathrm{O}_{3}$ ) will form an L-shape: in the troposphere an almost constant mixing ratio of the stratospheric tracer and much variation in the mixing ratio of the tropospheric tracer, and the opposite in the upper TTL and stratosphere. Thus, the correlation plot exhibits two distinct branches for the stratosphere and the troposphere, which meet in the lower TTL. Mixing following overshooting would again be seen along mixing lines between these two branches, connecting boundary layer observations with values observed at the highest level of overshoot.

Figure 5 shows the correlation plot between $\mathrm{O}_{3}$ and $\mathrm{CO}_{2}$ for the local flights, coloured according to potential temperatures and with the average correlation in black. The figure shows a flipped $\mathrm{L}$-shape with variable $\mathrm{CO}_{2}$ mixing ratios and constant $\mathrm{O}_{3}$ mixing ratios in the troposphere up to about $360 \mathrm{~K}$, and above that increasing $\mathrm{O}_{3}$ mixing ratios and slowly decreasing $\mathrm{CO}_{2}$ mixing ratios. Again, the correlation plot shows a deviation from the average correlation curve be-

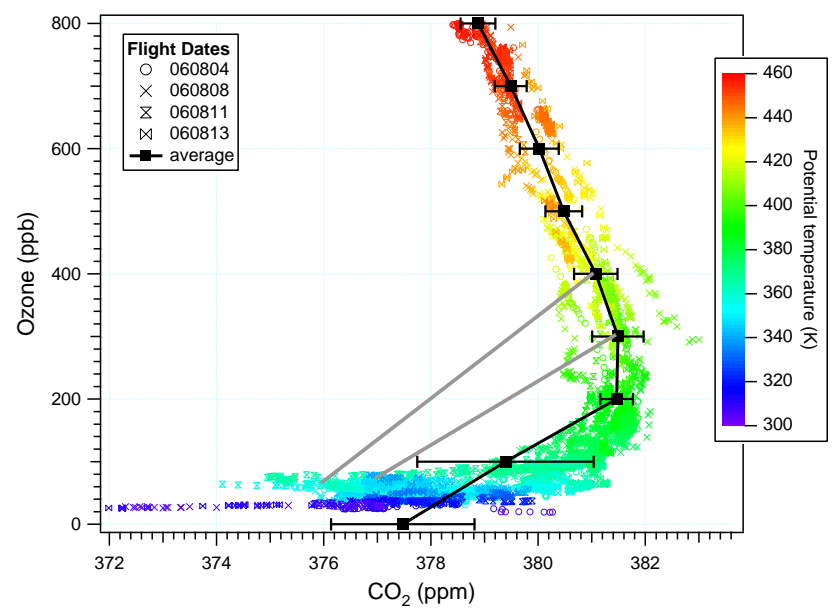

Fig. 5. Correlation between $\mathrm{O}_{3}$ and $\mathrm{CO}_{2}$. The data are coloured to potential temperature. The black line represents the average $\mathrm{CO}_{2}$ profile for all local flights. The grey lines are the possible mixing lines that are also displayed in Fig. 4.

tween potential temperatures of about 360 and $420 \mathrm{~K}$. They occur along mixing lines corresponding to those displayed in Fig. 4. However, similar signatures are not observed during that part of the flight in other species like $\mathrm{H}_{2} \mathrm{O}, \mathrm{NO}_{\mathrm{y}}$ and particles (not shown). If overshooting of convection had occurred one would expect clear signals of enhanced $\mathrm{H}_{2} \mathrm{O}$ and particles as moister air with more particles from the boundary layer would be entrained. Voigt et al. (2008) indicate layers with enhanced particles and $\mathrm{NO}_{\mathrm{y}}$, but these are found at other locations during the flight. The latter study does, however, show with backtrajectories that the air measured during this flight was located above a mesoscale convective system for at least 1.5 days prior to the measurements, with cloud top levels up to at least $120 \mathrm{hPa}$ ( $16 \mathrm{~km}$ altitude).

As during the flight of 7 August $\mathrm{CO}_{2}$ was not measured due to failure of the HAGAR instrument we examine the $\mathrm{CO}$ data measured by the COLD instrument. Figure 6 shows the $\mathrm{CO}$ profiles for both 7 and 8 August (the only flights during which COLD measured). Around $410 \mathrm{~K}$, very high CO mixing ratios are observed, which could again be an indication of vertical mixing following overshooting. This feature is also present in the correlation plot between $\mathrm{CO}$ and $\mathrm{O}_{3}$ (not shown here). However, as the two possible mixing lines in Fig. 6 indicate, this would imply mixing of air from the main convective outflow level $(355 \mathrm{~K})$ with air parcels at potential temperatures of at least $430 \mathrm{~K}$, i.e. overshoot to extremely high levels. Again, other tracers do not show similar signatures. Although enhancements are observed in mixing ratios of $\mathrm{NO}_{\mathrm{y}}$ and $\mathrm{CCN}$ during that day, these only indicate an influence up to $14-15 \mathrm{~km}$, and during a later section of the flight (not shown). Water vapour mixing ratios do not show any signatures indicative of overshooting convection (not shown). 


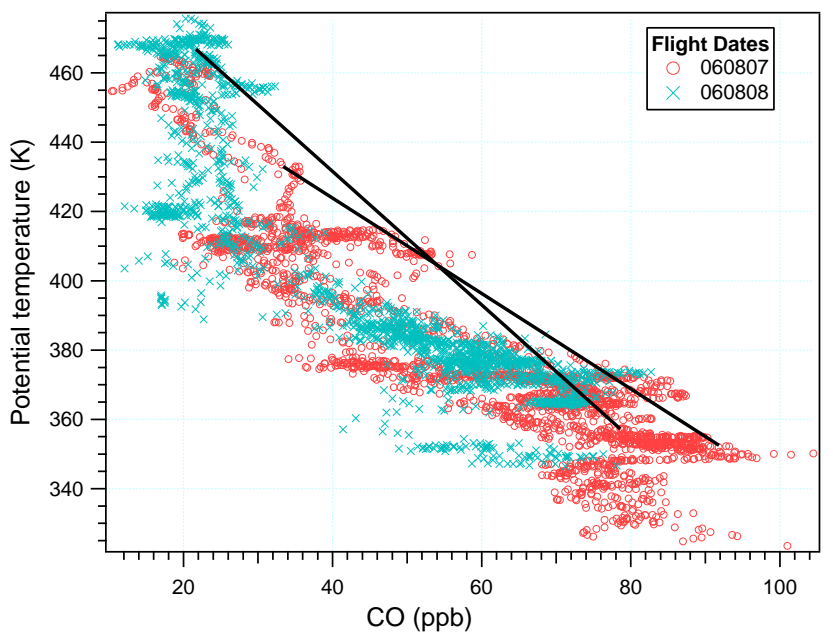

Fig. 6. CO profiles for 7 and 8 August. The black lines represent the two most extreme possible mixing lines that could explain the high $\mathrm{CO}$ values at $410 \mathrm{~K}$. One mixing line would mean mixing of air parcels with a potential temperature of $355 \mathrm{~K}$ and $430 \mathrm{~K}$, the other line mixing of air parcels with potential temperatures of $355 \mathrm{~K}$ and $470 \mathrm{~K}$. Any mixing line in between these two extremes is possible to explain the enhanced $\mathrm{CO}$ values at $410 \mathrm{~K}$.

Overall, we conclude that signatures potentially indicating impact of overshooting convection are observed in the lower stratosphere in the $\mathrm{CO}$ and $\mathrm{CO}_{2}$ mixing ratios during the AMMA campaign. However, these signatures are not corroborated by measurements from other instruments on board the airplane. Thus, evidence for the impact of overshooting is inconclusive. In particular, there is no clear indication that overshooting of convection plays a major role in troposphereto-stratosphere transport during the time of the campaign.

\subsection{Stratospheric isentropic inmixing into the TTL}

Horizontally, the tropical tropopause layer is confined by the subtropical jets. The strength and position of these jets vary by season, with a strong jet close to the equator in the winter hemisphere and a weak, poleward shifted jet in the summer hemisphere.Haynes and Shuckburgh (2000) show that a strong subtropical jet forms an effective transport barrier for the meridional, isentropic transport between the lower part of the TTL and the extratropical lower stratosphere. Isentropic, quasi-horizontal transport from the extra-tropical stratosphere may play a significant role in determining the chemical (trace species) and radiative character of the TTL (Gettelman and Forster, 2002). Analysis of previous aircraft measurements suggests that there may be significant quasiisentropic transport from the lower mid-latitude stratosphere toward the tropics (Tuck et al., 2003; Marcy et al., 2007).

In order to quantify the amount of extratropical stratospheric air entering the TTL we examine the $\mathrm{N}_{2} \mathrm{O}$ data. $\mathrm{N}_{2} \mathrm{O}$ has its source located at the surface and is well mixed

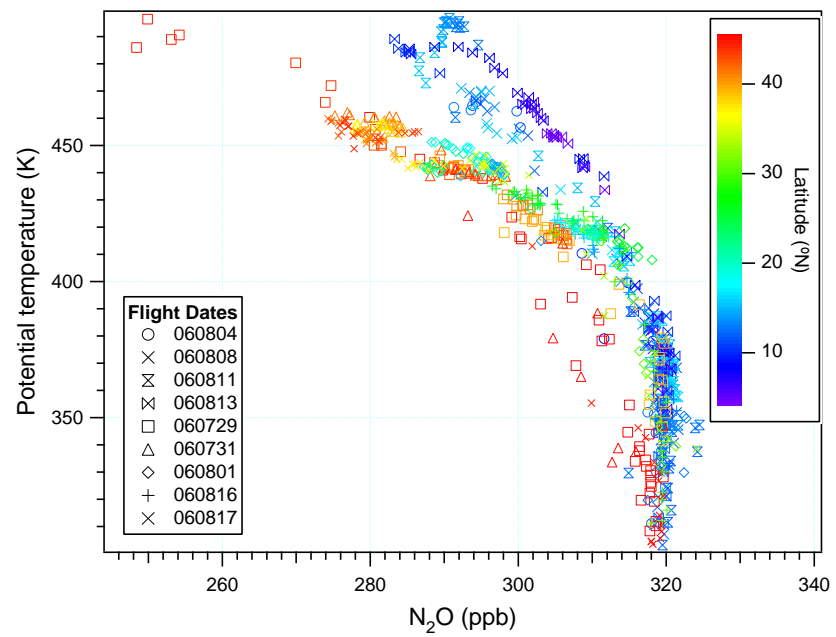

Fig. 7. Vertical profile of $\mathrm{N}_{2} \mathrm{O}$ coloured to latitude.

throughout the troposphere. Photochemical sinks in the midstratosphere result in declining $\mathrm{N}_{2} \mathrm{O}$ mixing ratios above the tropopause. Reductions in $\mathrm{N}_{2} \mathrm{O}$ mixing ratios below the typical tropospheric value therefore indicate entrainment of stratospheric, photochemically aged (in the order of years) air masses.

The profiles of $\mathrm{N}_{2} \mathrm{O}$ shown in Fig. 7 exhibit constant tropospheric concentrations for the local flights, and a well defined decrease from the tropopause upward, indicating that mixing with stratospherical older air masses is exceedingly rare below the tropopause, whereas the decrease just above the tropopause indicates increasing in-mixing of older air masses. The measurements made in Verona and during the transfer flights $\left(>30^{\circ} \mathrm{N}\right)$ show decreasing $\mathrm{N}_{2} \mathrm{O}$ values above $330 \mathrm{~K}$, indicating the level of the tropopause in the extratropical region.

In order to estimate the fraction of air transported from the extratropical lower stratosphere the $\mathrm{N}_{2} \mathrm{O}$ mixing ratios of the extratropical stratosphere are compared with the values in the TTL. The fraction of aged extratropical air $(\chi)$ can be expressed as:

$\chi=\frac{\left[\mathrm{N}_{2} \mathrm{O}\right]-\left[\mathrm{N}_{2} \mathrm{O}\right]_{\text {trop }}}{\left[\mathrm{N}_{2} \mathrm{O}\right]_{\text {extratrop }}-\left[\mathrm{N}_{2} \mathrm{O}\right]_{\text {trop }}}$,

where $\left[\mathrm{N}_{2} \mathrm{O}\right]$ is the measured $\mathrm{N}_{2} \mathrm{O}$ mixing ratio; $\left[\mathrm{N}_{2} \mathrm{O}\right]_{\text {trop }}$ is the average $\mathrm{N}_{2} \mathrm{O}$ mixing ratio at the bottom of the TTL, inferred as the average between potential temperatures of $320 \mathrm{~K}$ and $350 \mathrm{~K}$ between $0-20^{\circ} \mathrm{N} ;\left[\mathrm{N}_{2} \mathrm{O}\right]_{\text {extratrop }}$ is the average $\mathrm{N}_{2} \mathrm{O}$ mixing ratio of the extratropical lowermost stratosphere, inferred as the average between potential temperatures of $350 \mathrm{~K}$ and $400 \mathrm{~K}$ during all flights northward of $40^{\circ} \mathrm{N}$. The values derived here are $\left[\mathrm{N}_{2} \mathrm{O}\right]_{\text {extratrop }}=309$ and $\left[\mathrm{N}_{2} \mathrm{O}\right]_{\text {trop }}=320 \mathrm{ppb}$.

Figure 8 shows the derived fraction of extratropical air in the TTL. The blue line represents the average height of the 


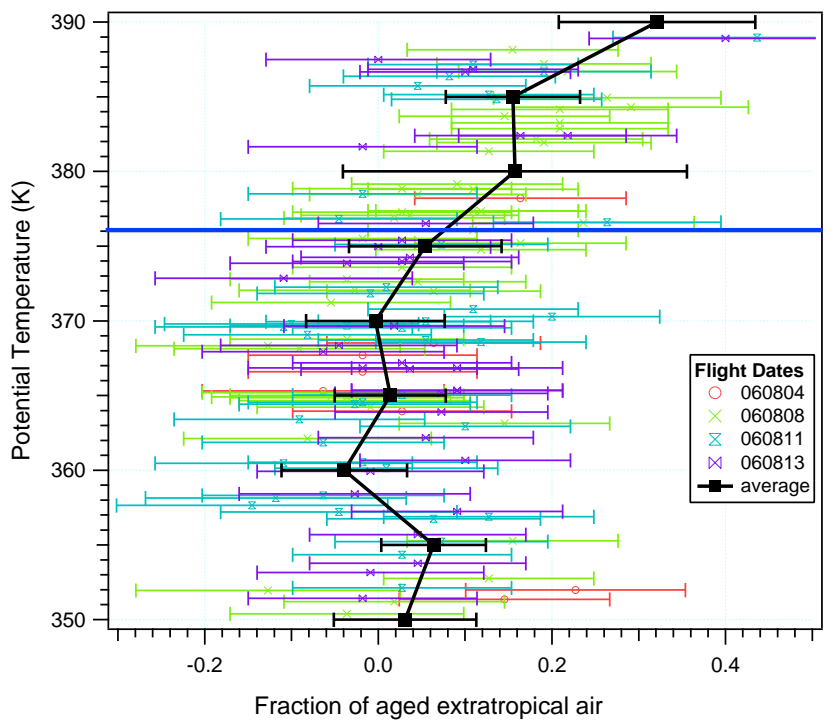

Fig. 8. Fraction of aged extratropical air. The blue line represents the average height of the tropopause.

cold point tropopause during the campaign. The fraction of aged extratropical air in the TTL is around zero in the lower part up to $370 \mathrm{~K}$ and is only slightly increasing towards the top of the TTL (here defined as the cold point tropopause). Note that this result refers to in-mixing of photochemically aged air only and thus does not necessarily rule out in-mixing of extra-tropical stratospheric air altogether. In fact active isentropic exchange across the weak summer subtropical jet with a net export of air masses from the TTL to the extratropical stratosphere is known to flush the lowermost stratosphere with young air over the course of the summer. Any re-entrainment of these young air masses into the TTL would not be detected by the above diagnostic (but would also be of little relevance for the chemical composition of the TTL).

\subsection{Isentropic mixing across the subtropical barrier}

Except for its lowest part where isentropic mixing with the extratropics is still relatively efficient, the tropical stratosphere is more or less isolated from the extratropical part of the stratosphere (Volk et al., 1996; Minschwaner et al., 1996). The subtropical barrier constitutes a region of strong horizontal shear and maximum PV gradient along isentropes, thereby prohibiting fast isentropic mixing between the tropical stratosphere and mid-latitude stratosphere, especially in the winter hemisphere.

Due to the isolation of the tropical stratosphere, tracer pairs with differing source/sink structures (e.g. $\mathrm{O}_{3}-\mathrm{N}_{2} \mathrm{O}$, $\mathrm{O}_{3}-\mathrm{NO}_{\mathrm{y}}$ ) show different correlation slopes in the tropical and extratropical stratosphere (Volk et al., 1996; Fahey et al., 1996). At mid-latitudes, where quasi-horizontal mixing is faster than both vertical transport and chemical time scales, a compact correlation evolves whose slope at any point is

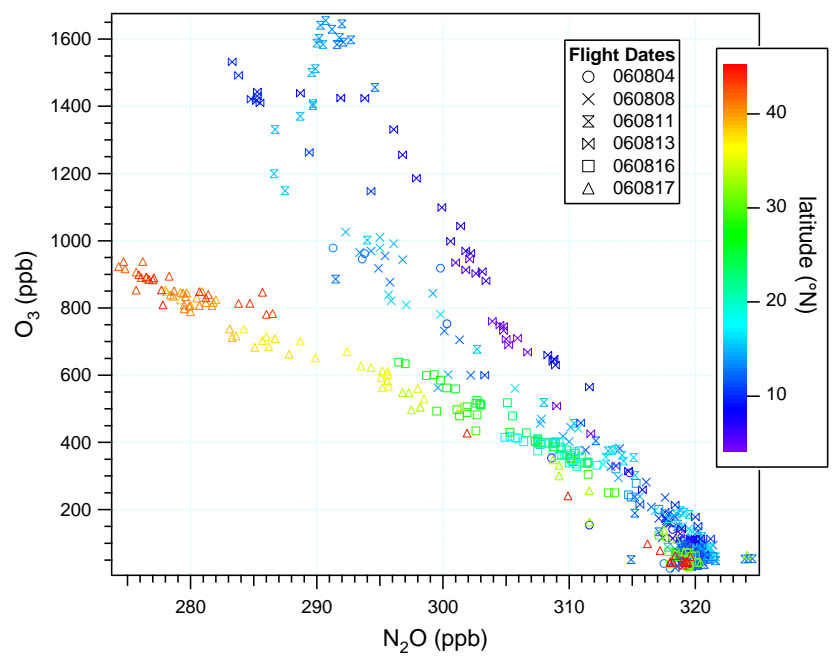

Fig. 9. Correlation between $\mathrm{N}_{2} \mathrm{O}$ and $\mathrm{O}_{3}$ coloured to latitude.

determined by the ratio of globally integrated sources and sinks of the two species above the given altitude (Plumb and Ko, 1992). Further, since the sources and sinks for $\mathrm{O}_{3}$ and $\mathrm{N}_{2} \mathrm{O}$ are insignificant in the lower stratosphere, this ratio remains approximately constant there, and thus the lower stratospheric correlation is fairly linear. In the tropics, on the other hand, quasi-horizontal mixing is slower, and the correlation is to a large part determined by vertical ascent and local chemistry (Volk et al., 1996); in situ production of $\mathrm{O}_{3}$ in the lower stratosphere thus results in a correlation slope different from the mid-latitudes. The correlation slope is therefore a reliable indicator for the origin of an air mass. A change in the slope of these correlation branches marks the position of the subtropical barrier. Mixing events between the two regions manifest themselves as lines or bands connecting the characteristic tropical and extratropical correlation branches.

Figure 9 shows the correlation between $\mathrm{O}_{3}$ and $\mathrm{N}_{2} \mathrm{O}$ for the local and the transfer flights during AMMA/SCOUT-O3. The colours indicate the latitude of the measurements. Different correlation slopes are observed at different latitudes.

The slopes of these correlations are visualised in Fig. 10 by plotting the ratio of the differences between the measured $\mathrm{O}_{3}$ and $\mathrm{N}_{2} \mathrm{O}$ values from tropospheric reference values, i.e. plotting the correlation slope from the tropospheric origin of the correlation (chosen as $320 \mathrm{ppb} \mathrm{N}_{2} \mathrm{O}$ and $50 \mathrm{ppb}$ $\mathrm{O}_{3}$ ). The figure shows only data above a potential temperature of $415 \mathrm{~K}$, above which a significant separation between the tropical and midlatitude correlations can be discerned. The lowest slope values of 0.02 observed southward of $15^{\circ} \mathrm{N}$ indicate air within the isolated tropical region (the "tropical pipe"), whereas the midlatitudes exhibit slope values exceeding 0.04. Values in between these extremes are found in a band between $10^{\circ} \mathrm{N}$ and $30^{\circ} \mathrm{N}$, suggesting a wider transition zone rather than a sharp subtropical barrier. In order to examine whether the subtropical barrier might nevertheless be 


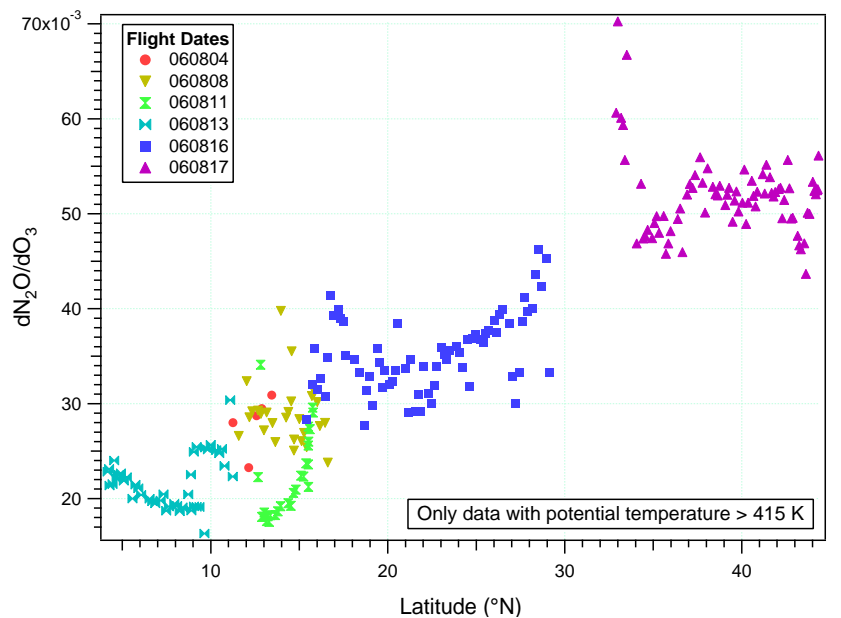

Fig. 10. Slope $\mathrm{dN}_{2} \mathrm{O} / \mathrm{dO}_{3}$ against latitude for the AMMA/SCOUTO3 flights.

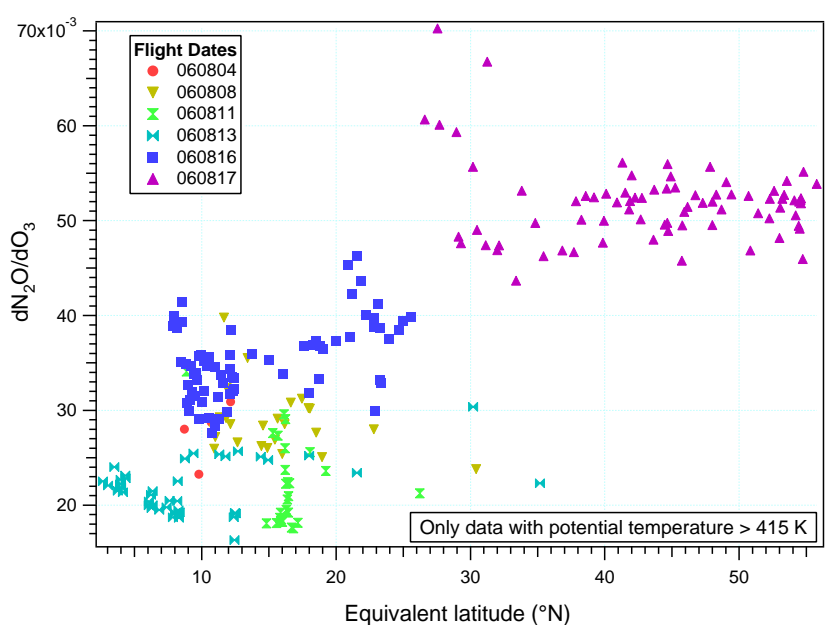

Fig. 11. Slope $\mathrm{dN}_{2} \mathrm{O} / \mathrm{dO}_{3}$ against equivalent latitude for the AMMA/SCOUT-O3 flights.

sharp, but undulate within that latitude band due to wave motions, we also plot the slope values against equivalent latitude in Fig. 11. Reversible wave motions should be mostly eliminated in this projection as they occur at roughly conserved potential vorticity, and thus equivalent latitude. Nevertheless, the transition between inner tropical and midlatitude slope values still spans a band between $10^{\circ} \mathrm{N}$ and $25^{\circ} \mathrm{N}$ equivalent latitude. It thus appears that during AMMA there is not a sharp barrier but a subtropical transition zone with a width of about $15^{\circ}$ latitude.

In Fig. 12 we compare our results with correlation slopes $\left(\mathrm{N}_{2} \mathrm{O}\right.$ vs. $\left.\mathrm{O}_{3}\right)$ found earlier during the ASHOE/MAESA campaign in March and October/November 1994. The slope values from AMMA data are coloured and plotted against latitude. The ASHOE/MAESA slopes (in grey) can be viewed in analogy to the $\mathrm{NO}_{\mathrm{y}} / \mathrm{O}_{3}$ ratios published in Fahey et al.

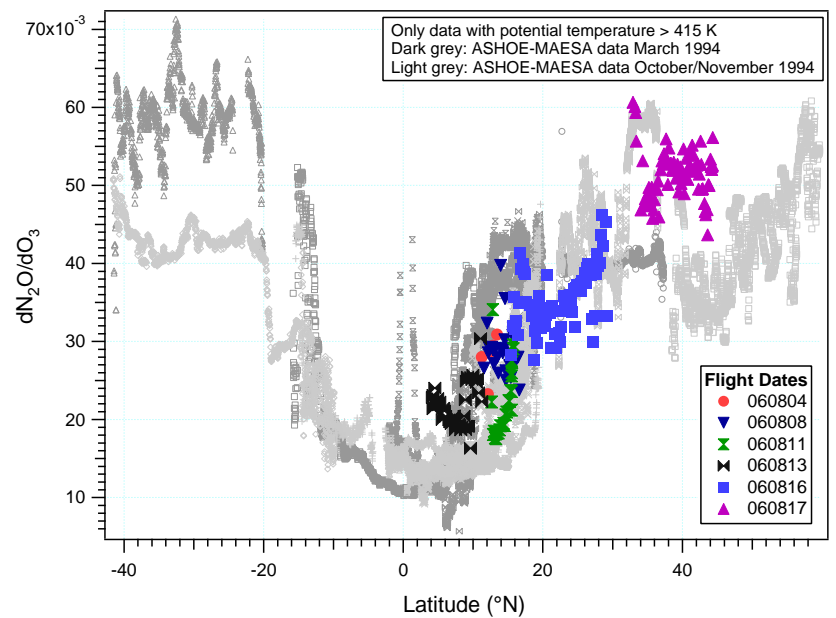

Fig. 12. Slope $\mathrm{dN}_{2} \mathrm{O} / \mathrm{dO}_{3}$ against latitude for the AMMA/SCOUT$\mathrm{O} 3$ (coloured) and ASHOE/MAESA (grey) flights.

(1996) and in fact show fairly sharp transitions between low tropical values and extratropical values in March (around $10^{\circ} \mathrm{N}$ ) and in October (around $15^{\circ} \mathrm{N}$ ). In contrast, the transition during AMMA in August is more gradual and ranges between $10^{\circ} \mathrm{N}$ and $25^{\circ} \mathrm{N}$. We note here that the ER-2 data from ASHOE/MAESA in the region in question are on average sampled at a higher altitude than the M55 Geophysica data from AMMA, the former being mostly collected during transfer flights at maximum altitude $(20-21 \mathrm{~km})$. As the subtropical barrier increases in strength above $20 \mathrm{~km}$, the ASHOE/MAESA data are thus expected to be more suitable to indicate the location and width of the barrier, whereas the Geophysica during AMMA may have sampled at an altitude range (below $20 \mathrm{~km}$ ) at which the barrier is weaker and thus more permeable to mixing. On the other hand, the subtropical barrier is also expected to be weakest during summer on the summer hemisphere due to the absence of strong wave activity in the surf zone, which tends to sharpen the barrier. Thus the observed differences between ASHOE/MAESA and AMMA in the width of the transition between tropical and extratropical tracer values may well be explained by differences in both sampling altitude and season.

\section{Conclusions}

We have presented in situ tracer data from the AMMASCOUT-O3 campaign in July/August 2006 over WestAfrica. Data were obtained on board the M55 Geophysica with the High Altitude Gas ANalyzer (HAGAR), measuring $\mathrm{CO}_{2}, \mathrm{~N}_{2} \mathrm{O}, \mathrm{CFC}-11, \mathrm{CFC}-12, \mathrm{H}-1211, \mathrm{CH}_{4}, \mathrm{SF}_{6}$ and $\mathrm{H}_{2}$, as well as from the FOZAN and COLD instruments, measuring $\mathrm{O}_{3}$ and $\mathrm{CO}$, respectively. We have used the data to examine the dominant transport processes in the 
TTL: deep convection up to the level of main convective outflow, irreversible mixing after overshooting of deep convection, isentropic inmixing into the TTL across the subtropical tropopause, and horizontal transport in the region of the stratospheric subtropical barrier. The $\mathrm{CO}_{2}$ profiles (with the exception of 13 August) show distinct minima in the TTL, reflecting the outflow of boundary layer air depleted in $\mathrm{CO}_{2}$. These reductions in $\mathrm{CO}_{2}$ suggest that i) convective influence in the TTL is quite significant in the sampled air masses and that ii) the main convective outflow was usually located at potential temperature levels up to $\sim 350-360 \mathrm{~K}(13-14 \mathrm{~km})$, and for the flight of 11 August even reached up to $370 \mathrm{~K}$ $(\sim 15 \mathrm{~km})$. The $\mathrm{O}_{3}$ profiles, on the other hand, indicate that the larger part of the convective fraction in the sampled air masses must be of rather older origin (several days or more), as regional boundary layer mixing ratios of $30 \mathrm{ppb}$ are only occasionally found in the TTL (only during the flight of 4 August), while average $\mathrm{O}_{3}$ mixing ratios in the TTL are observed to be $50 \mathrm{ppb}$ or higher. These results agree with those of Law et al. (2010) who find that a large part of the measured air was already residing in the tropical upper troposphere and lower stratosphere when arriving over West Africa and was uplifted over Asia within ten days prior to the measurements. According to their study, regional uplift over Africa above $350 \mathrm{~K}$ was only important on 11 August, and potentially on 8 August. Overshooting convection does not appear to have a large impact on vertical profiles of gas-phase tracers, which exhibit quite coherent shapes above the maximum level of convective outflow. Only a few small signatures potentially indicative of mixing following overshooting convection were observed in the $\mathrm{CO}_{2}$ data during the flights of 4 and 8 August; another potential signature was observed in $\mathrm{CO}$ on 7 August. However, similar signatures were not simultaneously observed in other tracers. The absence of frequent high reaching local convection and the lack of major overshooting events impacting the gas-phase composition of the TTL inferred in this study is in accord with the notion that the African region is not a major player in troposphereto-stratosphere transport (Berthet et al., 2007; Barret et al., 2008), at least not in $\mathrm{NH}$ summer.

Stratospheric inmixing of photochemically aged air from the extratropical stratosphere appears to be minimal up to the mean local tropopause at $376 \mathrm{~K}$. The fractions of aged extratropical air in the TTL, as estimated from $\mathrm{N}_{2} \mathrm{O}$ profiles is $0.0 \pm 0.1$ up to $370 \mathrm{~K}$ and is increasing above this level up to about $0.3 \pm 0.1$ at $390 \mathrm{~K}$.

The subtropical barrier does not manifest itself as a sharp boundary in tracer distributions, but rather as a gradual transition region between around $10^{\circ} \mathrm{N}$ and $25^{\circ} \mathrm{N}$ where tracer mixing ratios change from characteristic tropical to extratropical values. The subtropical barrier thus appears to be rather permeable to horizontal mixing in the summer subtropics below $20 \mathrm{~km}$ altitude.
Acknowledgements. This research was supported by the European Community under the Integrated Projects SCOUT-O3 (505390GOCE-CT-2004) and AMMA-EU (Contract Number 004089-2), as well as by the EEIG-Geophysica Consortium, EUFAR, CNRSINSU, and CNES.

Based on a French initiative, AMMA was built by an international scientific group and is currently funded by a large number of agencies, especially from France, UK, US and Africa. It has been the beneficiary of a major financial contribution from the European Community's Sixth Framework Research Programme. Detailed information on scientific coordination and funding is available on the AMMA International web site http://www.amma-international.org. We also would like to thank the pilot and the crew of the M55 Geophysica as well as our colleagues, the local scientists and the representatives in Burkina Faso, who made the AMMA-SCOUTO3 campaign a success. Finally we are grateful to Horst Fischer for support with the implementation of the Licor $\mathrm{CO}_{2}$ sensor within the HAGAR instrument and to Oliver Riediger for his help during the campaign.

Edited by: C. Reeves

\section{References}

AMMA Public: http://www.amma-international.org/rubrique. php3?id_rubrique $=1$,

last access: 25 May 2009.

Andrews, A. E., Boering, K. A., Daube, B. C., Wofsy, S. C., Hintsa, E. J., Weinstock, E. M., and Bui, T. P.: Empirical age spectra for the lower tropical stratosphere from in situ observations of CO2: Implications for stratospheric transport, J. Geophys. Res., 104(D21), 26581-26596, 1999.

Arteta, J., Marécal, V., and Rivière, E. D.: Regional modelling of tracer transport by tropical convection - Part 1: Sensitivity to convection parameterization, Atmos. Chem. Phys., 9, 70817100, 2009,

http://www.atmos-chem-phys.net/9/7081/2009/.

Barret, B., Ricaud, P., Mari, C., Attié, J.-L., Bousserez, N., Josse, B., Le Flochmoën, E., Livesey, N. J., Massart, S., Peuch, V.H., Piacentini, A., Sauvage, B., Thouret, V., and Cammas, J.P.: Transport pathways of $\mathrm{CO}$ in the African upper troposphere during the monsoon season: a study based upon the assimilation of spaceborne observations, Atmos. Chem. Phys., 8, 3231-3246, 2008 , http://www.atmos-chem-phys.net/8/3231/2008/.

Barret, B., Williams, J. E., Bouarar, I., Yang, X., Josse, B., Law, K., Pham, M., Le Flochmoën, E., Liousse, C., Peuch, V. H., Carver, G. D., Pyle, J. A., Sauvage, B., van Velthoven, P., Schlager, H., Mari, C., and Cammas, J.-P.: Impact of West African Monsoon convective transport and lightning NOx production upon the upper tropospheric composition: a multi-model study, Atmos. Chem. Phys. Discuss., 10, 2245-2302, 2010,

http://www.atmos-chem-phys-discuss.net/10/2245/2010/.

Berthet, G., Esler, J. G., and Haynes, P. H.: A Lagrangian perspective of the tropopause and the ventilation of the lowermost stratosphere, J. Geophys. Res., 112, D18102, doi:10.1029/2006JD008295, 2007. 
Boering, K. A., Wofsy, S. C., Daube, B. C., Schneider, H. R., Loewenstein, M., and Podolske, J. R.: Stratospheric mean ages and transport rates from observations of carbon dioxide and nitrous oxide, Science, 274(5291), 1340-1343, 1996.

Cairo, F., Buontempo, C., MacKenzie, A. R., Schiller, C., Volk, C. M., Adriani, A., Mitev, V., Matthey, R., Di Donfrancesco, G., Oulanovsky, A., Ravegnani, F., Yushkov, V., Snels, M., Cagnazzo, C., and Stefanutti, L.: Morphology of the tropopause layer and lower stratosphere above a tropical cyclone: a case study on cyclone Davina (1999), Atmos. Chem. Phys., 8, 34113426, 2008,

http://www.atmos-chem-phys.net/8/3411/2008/.

Cairo, F., Pommereau, J. P., Law, K. S., Schlager, H., Garnier, A., Fierli, F., Ern, M., Streibel, M., Arabas, S., Borrmann, S., Berthelier, J. J., Blom, C., Christensen, T., D'Amato, F., Di Donfrancesco, G., Deshler, T., Diedhiou, A., Durry, G., Engelsen, O., Goutail, F., Harris, N. R. P., Kerstel, E. R. T., Khaykin, S., Konopka, P., Kylling, A., Larsen, N., Lebel, T., Liu, X., MacKenzie, A. R., Nielsen, J., Oulanowski, A., Parker, D. J., Pelon, J., Polcher, J., Pyle, J. A., Ravegnani, F., Rivire, E. D., Robinson, A. D., Rckmann, T., Schiller, C., Simes, F., Stefanutti, L., Stroh, F., Some, L., Siegmund, P., Sitnikov, N., Vernier, J. P., Volk, C. M., Voigt, C., von Hobe, M., Viciani, S., and Yushkov, V.: An introduction to the SCOUT-AMMA stratospheric aircraft, balloons and sondes campaign in West Africa, August 2006: rationale and roadmap, Atmos. Chem. Phys., 10, 2237-2256, 2010,

http://www.atmos-chem-phys.net/10/2237/2010/.

Danielsen, E. F.: A dehydration mechanism for the stratosphere, Geophys. Res. Lett., 9(6), 605-608, 1982.

Danielsen, E. F.: In situ evidence of rapid, vertical, irreversible transport of lower tropospheric air into the lower tropical stratosphere by convective cloud turrets and by larger-scale upwelling in tropical cyclones, J. Geophys. Res., 98, 8665-8681, 1993.

Fahey, D. W., Donelly, S. G., Keim, E. R., Gao, R. S., Wamsley, R. C., Del Negro, L. A., Woodbridge, E. L., Proffitt, M. H., Rosenlof, K. H., Ko, M. K. W., Weisenstein, D. K., Scott, C. J., Nevison, C., Solomon, S., and Chan, K. R.: In situ observations of $\mathrm{NO}_{\mathrm{y}}, \mathrm{O}_{3}$ and the $\mathrm{NO}_{\mathrm{y}} / \mathrm{O}_{3}$ ratio in the lower stratosphere, Geophys. Res. Lett., 23, 1653-1656, 1996.

Folkins, I., Loewenstein, M., Podolske, J., Oltmans, S. J. and Profitt, M.: A barrier to vertical mixing at $14 \mathrm{~km}$ in the tropics: Evidences from ozonesondes and aircraft measurements, J. Geophys. Res., 104, 22095-22102, 1999.

Folkins, I. and Martin, R. V.: The vertical structure of tropical convection and its impact on the budgets of water vapor and ozone, J. Atmos. Sci., 62, 1560-1573, 2005.

Folkins, I., Oltmans, S. J., and Thompson, A. M.: Tropical convective outflow and near surface equivalent potential temperatures, Geophys. Res. Lett., 27, 2549-2552, 2000.

Fridlind, A. M., Ackerman, A. S, Jensen, E.J., Heymsfield, A.J., Poellot, M. R., Stevens, D. E., Wang, D., Miloshevich, L. M., Baumgardner, D., Lawson, R. P., Wilson, J. C., Flagan, R. C., Seinfeld, J. H., Jonsson, H. H., VanReken, T. M., Varutbangkul, V., and Rissman, T. A.: Evidence for the predominance of midtropospheric aerosols as subtropical anvil cloud nuclei., Science, 304(5671), 718-722, 2004.

Fueglistaler, S., Wernli, H., and Peter, T: Tropical troposphere to stratosphere transport inferred from trajectory calculations, J. Geophys. Res., 109, D03108, doi:10.1029/2003JD004069, 2004.
Gettelman, A. and Forster, P. M.: A climatology of the tropical tropopause layer, J. Meteorol. Soc. Japan, 80, 911-924, 2002.

Haynes, P. and Shuckburgh, E.: Effective diffusivity as a diagnostic of atmospheric transport 2. troposphere and lower stratosphere, J. Geophys. Res., 105, 22795-22810, 2000.

Hoor, P., Fischer, H., Lange, L., Lelieveld, J., and Brunner, D.: Seasonal variations of a mixing layer in the lowermost stratosphere as identified by the CO-O3 correlation from in situ measurements, J. Geophys. Res., 107(D5), 4044, doi:10.1029/2000JD000289, 2002.

Janicot, S., Thorncroft, C. D., Ali, A., Asencio, N., Berry, G., Bock, O., Bourles, B., Caniaux, G., Chauvin, F., Deme, A., Kergoat, L., Lafore, J.-P., Lavaysse, C., Lebel, T., Marticorena, B., Mounier, F., Nedelec, P., Redelsperger, J.-L., Ravegnani, F., Reeves, C. E., Roca, R., de Rosnay, P., Schlager, H., Sultan, B., Tomasini, M., Ulanovsky, A., and ACMAD forecasters team: Large-scale overview of the summer monsoon over West Africa during the AMMA field experiment in 2006, Ann. Geophys., 26, 25692595, 2008, http://www.ann-geophys.net/26/2569/2008/.

Khaykin, S., Pommereau, J.-P., Korshunov, L., Yushkov, V., Nielsen, J., Larsen, N., Christensen, T., Garnier, A., Lukyanov, A., and Williams, E.: Hydration of the lower stratosphere by ice crystal geysers over land convective systems, Atmos. Chem. Phys., 9, 2275-2287, 2009,

http://www.atmos-chem-phys.net/9/2275/2009/.

Konopka, P., Gnther, G., Müller, R., dos Santos, F. H. S., Schiller, C., Ravegnani, F., Ulanovsky, A., Schlager, H., Volk, C. M., Viciani, S., Pan, L. L., McKenna, D.-S., and Riese, M.: Contribution of mixing to upward transport across the tropical tropopause layer (TTL), Atmos. Chem. Phys., 7, 3285-3308, 2007, http://www.atmos-chem-phys.net/7/3285/2007/.

Law, K.S., Fierli, F., Cairo, F., Schlager, H., Borrman, S., Ravegnani. F., Real, E., Kunkel, D., Schiller, C., Streibel, M., Ulanovsky, A., Viciani, S., Volk, C.M.: Air mass origins influencing TTL chemical composition over West Africa during the 2006 summer monsoon, Atmos. Chem. Phys. Discuss., in preparation, 2010.

Liu, C. and Zipser, E. J.: Global distribution of convection penetrating the tropical tropopause, J. Geophys. Res., 110, D23104, doi:10.1029/2005JD006063, 2005.

Liu, X. M., Rivière, E. D., Marécal, V., Durry, G., Hamdouni, A., Arteta, J., and Khaykin, S.: Water vapor budget associated to overshoots in the tropical stratosphere: mesoscale modelling study of 4-5 August 2006 during SCOUT-AMMA, Atmos. Chem. Phys. Discuss., 10, 3975-4025, 2010,

http://www.atmos-chem-phys-discuss.net/10/3975/2010/.

MacKenzie, A. R., Schiller, C., Peter, Th., Adriani, A., Beuermann, J., Bujok, O., Cairo, F., Corti, T., DiDonfrancesco, G. Gensch, I., Kiemle, C., Krämer, M., Kröger, C., Merkulov, S., Oulanovsky, A., Ravegnani, F., Rohs, S., Rudakov, V., Salter, P., Santacesaria, V., Stefanutti, L., and Yushkov, V.: Tropopause and hygropause variability over the equatorial Indian Ocean during February and March 1999, J. Geophys. Res., 111, D18112, doi:10.1029/2005JD006639, 2006.

Marcy T. P., Popp, P. J., Gao, R. S., Fahey, D. W., Ray, E. A., Richard, E. C., Thompson, T. L., Atlas, E. L., Loewenstein, M., Wofsy, S. C., Park, S., Weinstock, E. M., Swartz, W. H., and Mahoney, M. J.: Measurements of trace gases in 
the tropical tropopause layer, Atmos. Environ., 41, 7253-7261, doi:10.1016/j.atmosenv.2007.05.032, 2007.

Minschwaner, K., Dessler, A. E., Elkins, J. W., Volk, C. M., Fahey, D. W., Loewenstein, M., Podolske, J. R., Roche, A. E., and Chan, K. R.: Bulk properties of isentropic mixing into the tropics in the lower stratosphere, J. Geophys. Res., 101, 9433-9439, 1996.

Park, S., Jiménez, R., Daube, B. C., Pfister, L., Conway, T. J., Gottlieb, E. W., Chow, V. Y., Curran, D. J., Matross, D. M., Bright, A., Atlas, E. L., Bui, T. P., Gao, R.-S., Twohy, C. H., and Wofsy, S. C.: The $\mathrm{CO}_{2}$ tracer clock for the Tropical Tropopause Layer, Atmos. Chem. Phys., 7, 3989-4000, 2007a, http://www.atmos-chem-phys.net/7/3989/2007/.

Park, M., Randel, W. J., Gettelman, A., Massie, S. T., and Jiang, J. H.: Transport above the Asian summer monsoon anticyclone inferred from Aura Microwave Limb Sounder tracers, J. Geophys. Res., 112, D16309, doi:10.1029/2006JD008294, 2007.

Plumb, R. A. and Ko, M. K. W.: Interrelationships between mixing ratios of long-lived stratospheric constituents, J. Geophys. Res., 97, 10145-10156, 1992.

Randel, W. J., Park, M., Wu, F., and Liveseya, N.: A large annual cycle in ozone above the tropical tropopause linked to the Brewer-Dobson Circulation, J. Atmos. Sci., 64, 4479-4488, doi:10.1175/2007JAS2409.1, 2007.

Reid, G. C. and Gage, K. S.: On the annual variation in the height of the tropical tropopause, J. Atmos. Sci., 38, 1928-1938, 1981.

Ricaud, P., Barret, B., Attié, J.-L., Motte, E., Le Flochmoën, E., Teyssèdre, H., Peuch, V.-H., Livesey, N., Lambert, A., and Pommereau, J.-P.: Impact of land convection on tropospherestratosphere exchange in the tropics, Atmos. Chem. Phys., 7, 5639-5657, 2007,

http://www.atmos-chem-phys.net/7/5639/2007/.

Riediger, O.: Entwicklung und Einsatz eines flugzeuggetragenen Instrumentes zur in-situ-Messung langlebiger Spurengase in der Stratosphäre, Ph.D. thesis, Johann Wolfgang Goethe Universität Frankfurt, Germany, 195 pp., 2000.

Rossow, W. B. and Pearl, C.: 22-Year survey of tropical convection penetrating into the lower stratosphere, Geophys. Res. Lett., 34, L04803, doi:10.1029/2006GL028635, 2007.

Sauvage, B., Martin, R. V., van Donkelaar, A., and Ziemke, J. R.: Quantification of the factors controlling tropical tropospheric ozone and the South Atlantic maximum, J. Geophys. Res., 112, D11309, doi:10.1029/2006JD008008, 2007.

Schiller, C., Grooß, J.-U., Konopka, P., Plöger, F., Silva dos Santos, F. H., and Spelten, N.: Hydration and dehydration at the tropical tropopause, Atmos. Chem. Phys., 9, 9647-9660, 2009, http://www.atmos-chem-phys.net/9/9647/2009/.

Sherwood, S. C.: A "stratospheric drain" over the maritime continent, Geophys. Res. Lett., 27, 677-680, 2000.
Stefanutti, L., MacKenzie, A. R., Santacesaria, V., Adriani, A., Balestri, S., Borrmann, S., Khattatov, V., Mazzinghi, P., Mitev, V., Rudakov, V., Schiller, C., Toci, G., Volk, C. M., Yushkov, V., Flentje, H., Kiemle, C., Redaelli, G., Carslaw, K. S., Noone, K., and Peter, T.: The APE-THESEO tropical campaign: an overview. J. Atmos. Chem., 48, 1-33, doi:10.1023/B:JOCH.0000034509.11746.b8, 2004.

Strunk, M.: An Experimental Study on the Mean Age of Stratospheric Air, Ph.D. thesis, Johann Wolfgang Goethe-Universität Frankfurt, Germany, 1999.

Sultan, B., Janicot, S., and Drobinski, P.: Characterization of the Diurnal Cycle of the West African Monsoon around the Monsoon Onset, J. Climate, 20, 4014-4032, 2007.

Thompson, A. M., Doddridge, B. G., Witte, J. C., Hudson, R. D., Luke, W. T., Johnson, J. E., Johnson, B. J., Oltmans, S. J., and Weller, R.: A tropical atlantic paradox: shipboard and satellite views of a tropospheric ozone maximum and wave-one in January-February 1999, Geophys. Res. Lett., 27, 3317-3320, 2000.

Tuck, A. F., Hovde, S. J., Kelly, K. K., Mahoney, M. J., Proffitt, M. H., Richard, E. C., and Thompson, T. L.: Exchange between the upper tropical troposphere and the lower stratosphere studied with aircraft observations, J. Geophys. Res., 108(D23), 4734, doi:10.1029/2003JD003399, 2003.

Ulanosvky, A. E., Yushkov, V. A., Sitnikov, N. M., and Ravegnani, F.: The FOZAN-II Fast-Response Chemiluminescent Airborne Ozone Analyzer, Instrum. Exp. Tech., 44(2), 249-256, 2001.

Vaughan G, Schiller, C. , MacKenzie, A. R., Bower, K., Peter, T., Schlager, H., Harris, N. R. P., and May, P. T.: SCOUTO3/ACTIVE: High-altitude aircraft measurements around deep tropical convection, BAMS, 89(5), 647-662, 2008.

Viciani, S., D’Amato, F., Mazzinghi, P., Castagnoli, F., Toci, G., and Werle, P.: A cryogenically operated laser diode spectrometer for airborne measurement of stratospheric trace gases, Appl. Phys. B, 90, 581-592, doi:10.1007/s00340-007-2885-2, 2008.

Voigt, C., Schlager, H., Roiger, A., Stenke, A., de Reus, M., Borrmann, S., Jensen, E., Schiller, C., Konopka, P., and Sitnikov, N.: Detection of reactive nitrogen containing particles in the tropopause region - evidence for a tropical nitric acid trihydrate (NAT) belt, Atmos. Chem. Phys., 8, 7421-7430, 2008, http://www.atmos-chem-phys.net/8/7421/2008/.

Volk, C. M., Elkins, J. W., Fahey, D. W., Salawitch, R. J., Dutton, G. S., Gilligan, J. M., Proffitt, M. H., Loewenstein, M., Podolske, J. R., Minschwaner, K., Margitan, J. J., and Chan, K. R.: Quantifying transport between the tropical and mid-latitude lower stratosphere, Science, 272, 1763-1768, 1996.

Zipser, E. J., Cecil, D. J., Liu, C. T., Nesbitt, S. W., and Yorti, D. P.: Where are the most intense thunderstorms on earth?, B. Am. Meteorol. Soc., 87(8), 1057-1071, 2006. 